\title{
Measurements of submarine groundwater discharge rates by a continuous heat-type automated seepage meter in Osaka Bay, Japan
}

\author{
Makoto TANIGUCHI * and Hiroteru IWAKAWA ** \\ 連続熱供給型湧出量計を用いた大阪湾における \\ 海底地下水湧出量の測定
}

谷口真人**·岩川浩照*

\begin{abstract}
In order to evaluate submarine groundwater discharge (SGD) rates continuously and automatically, a "continuous heat-type" automated seepage meter was newly developed, and it was applied to Tannowa, Osaka Bay, Japan. The meter is based on the measurements of the temperature gradient of the water between the downstream and upstream positions in a pipe. According to two months continuous measurements of SGD every 10 minutes, semi-diurnal periodical changes in SGD were found in Tannowa. This is attributed to the tidal effects on SGD. The time delay of the SGD from tidal records was also found to be about 5 hours. The newly developed automated seepage meter can provide longer-term and higher-resolution measurements of SGD, which helps us to understand temporal scale issues on SGD and the relevant hydrological and coastal oceanographic processes.
\end{abstract}

Key Words: submarine groundwater discharge, continuous heat, automated seepage meter, Osaka Bay, tidal effect

* Department of Earth Sciences, Nara University of Education

** Graduate Student, Nara University of Education 


\section{要 旨}

海底地下水湧出量を連続的かつ自動的に測定するために，連続熱供給型湧出量計を新た に開発し、大阪湾南部の淡輪において適用した。開発した湧出量計は、熱移流によって生 じる水パイプの上流側と下流側との温度差を測定することにより、湧出地下水量を連続測 定できる仕組みになっている。10分間隔で約 2 ケ月間の連続自動測定の結果、ほほ半日周 期の湧出量変化が観測され、この变動は潮汋の影響であることが明らかになった。また、 海底地下水湧出が潮汐による潮位の変動に対して、約 5 時間遅れることが明らかになっ た。今回開発した湧出量計は, 長期間・高分解能で海底地下水湧出量を連続測定すること ができ, 沿岸域の水文学的・海洋学的プロセスを明らかにするために有効であると考えら れる。

キーワード：海底地下水湧出、連続熱供給、自動湧出量計、大阪湾、潮汐の影響

\section{Introduction}

Submarine groundwater discharge (SGD) is now recognized as a potentially significant material pathway from the land to the ocean (Burnett, 1999). There are several methods to evaluate the SGD rates, such as tracer methods, water balance methods, numerical simulation methods, and the methods using piezometers and seepage meters. The only method to measure SGD directly is the use of seepage meter.

Measurements of groundwater seepage rate into surface water bodies are often made using manual "seepage meters" in the fields of limnology and hydrology. This device was first developed by Israelsen and Reeve (1944) to measure the water loss from irrigation canals. Lee (1977) designed a seepage meter consisting of one end of a 55-gallon (208 liters) steel drum which is fitted with a sample port and a plastic collection bag. The drum forms a chamber which is inserted open end down into the sediment. The water seeping from the sediment will displace the water trapped in the chamber forcing it up through the port into the top plastic bag. The change in volume of water in the bag over a measured time interval provides the flux meas- urement.

Studies involving seepage meters have reached the following general conclusions (Taniguchi, 2001; Taniguchi et al., 2001): (1) many seepage meters are needed because of the natural spatial and temporal variability of seepage flow rates (Shaw and Prepas, 1990a, b); (2) the resistance of the tube (Fellows and Brezonik, 1980) and bag (Shaw and Prepas, 1989; Belanger and Montgomery, 1992) should be minimized to the degree possible to remove the effects of the artifacts; (3) use of a cover for the collection bag may reduce the effect of surface water movement due to wave, current or streamflow activity (Libelo and MacIntyre, 1994); and (4) the detection limit of a seepage meter should be applied (Cable et al., 1997a). The problems using seepage meters are discussed in detail by Taniguchi (2001) and Taniguchi et al. (2001).

Despite these potential errors and detection limits, a recent field evaluation of "Lee-type" manual seepage meters showed that consistent and reliable results can be obtained if one takes these potential problems into account (Cable et al., 1997a,b). This seems to be especially true in areas where flux rates are fairly high $(>3$ 
$\mathrm{cm} /$ day). They are commonly employed to determine groundwater - surface water interactions near the lakes since the 1970's, and are increasingly utilized in coastal marine environments for studies where simple, inexpensive methods may be required.

The most serious disadvantage for evaluating SGD directly is that the traditional manual seepage meters are very labor intensive. In order to obtain the groundwater discharge rate automatically and continuously, various types of automated seepage meters have been developed. Installations of seepage meters remotely from the surface of various water bodies were attempted by Fukuo (1986), Cherkauer and McBride (1988), and Boyle (1994). Sayles and Dickinson (1990) constructed a seepage meter which is a benthic chamber for the sampling and analysis of seepage through sediments associated with hydrothermal vents. Flow meters based on ultrasonic measurements are also used to evaluate seepage flow (Paulsen et al., 1997). One example of such an automated approach for measurement of SGD rate is the heat-pulse device described by Taniguchi and Fukuo (1993, 1996) and a similar device constructed by Krupa et al. (1998).

The purposes of this study are (1) to develop a new type (continuous heat-type) of automated seepage meter which is more user friendly than the previous meters and is easy to be assembled from the sensors which are commercially available, and (2) to apply the new automated seepage meters to evaluate the changes in submarine groundwater discharge rates in Osaka Bay, Japan.

\section{Development of continuous heat-type automated seepage meter}

A "continuous heat-type" automated seepage meter uses the effects of heat convection caused by water flow. The principle of the method is to measure the temperature gradient of the water flowing between the downstream (sensor A) and upstream (sensor B) positions in a flow tube with a diameter of $1.3 \mathrm{~cm}$ (Figure 1). The distance between sensors A and B is $15 \mathrm{~cm}$. The temperature gradient is caused by the heat continuously generated within the column. This method is so called "Granier method" (Granier, 1985), and used in many measurements such as detecting the water flux in trees (sap flow sensors). When there is no water flow, the temperature difference between sensors $\mathrm{A}$ and $\mathrm{B}$ in the column is the maximum, and it decreases with increasing the water flow velocity. Calibrations of the sensors are made in the laboratory under the control of the water flux in the pipe. Measurements using this meter are based on the widely used technique of placing a chamber into the seabed to capture SGD (Figure 1). The sampling frequency and duration are programmed into the logger.

Figure 2 shows some of calibration results with different velocity of the water in the pipe against time. As can be seen from Figure 2, it takes only several minutes to reach to the steady state when the velocity of the water in a pipe is high $(508.5 \mathrm{~cm} / \mathrm{h})$. On the other hand, it takes 20 to 30 minutes when the velocity of the water in the pipe is low as $6.8 \mathrm{~cm} / \mathrm{h}$. When we

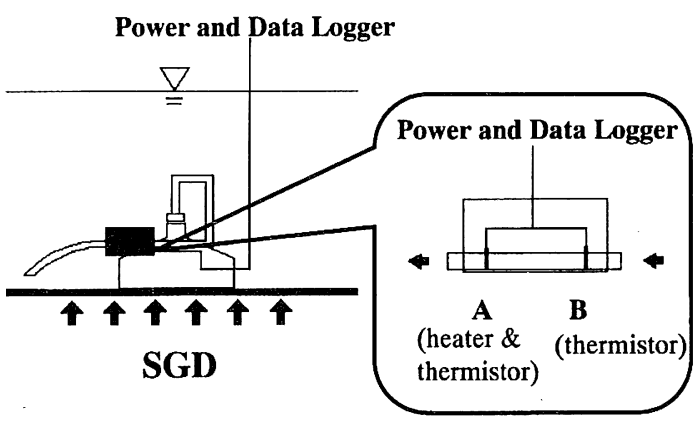

Figure 1 Schematic diagram of a continuous heat-type automated seepage meter. A diameter and a length of the pipe are $1.3 \mathrm{~cm}$ and $15 \mathrm{~cm}$, respectively. 
use a chamber with the area of $0.255 \mathrm{~m}^{2}$, the water velocity of $6.8 \mathrm{~cm} / \mathrm{h}$ in the pipe corresponds to $9.8 \times 10^{-9} \mathrm{~m} / \mathrm{s}$. Therefore, this time lag is less than 30 minutes when the SGD flux is more than $10^{-8} \mathrm{~m} / \mathrm{s}$ with the ordinary chamber $\left(0.255 \mathrm{~m}^{2}\right)$.

Figure 3 shows a relationship between output voltage which is generated from the temperature gradient between upstream and downstream in the water pipe, and the velocity of the water in the pipe. The calibration curve of the sensor obtained by the least-squares method is;

$$
\mathrm{Y}=-0.0558 \operatorname{Ln}(\mathrm{X})+0.8109\left(\mathrm{R}^{2}=0.9764\right)
$$

where $\mathrm{X}$ is the output voltage $(\mathrm{V})$ and $\mathrm{Y}$ is the water velocity $(\mathrm{cm} / \mathrm{h})$ in the pipe.

As can be seen from Figure 3, the output voltage which is correlated to the temperature gradient between two sensors in the pipe, decreases with increasing water velocity. Therefore, we can obtain SGD rates from this calibration curve and the output voltage with the areal ratio of the chamber and the pipe.

\section{Study area}

The study area is located in Tannowa, south of Osaka Bay, Japan (Figure 4). The sea-

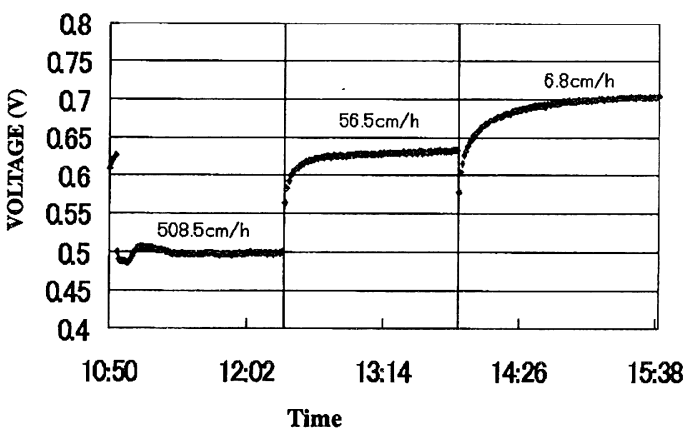

Figure 2 Calibration results for the seepage meter with different velocities of the water in a pipe against time. bed surface consists of muddy sand, and some sea glasses are found in the area. The annual precipitation is about $1400 \mathrm{~mm} / \mathrm{year}$, and annual air temperature is $16.2{ }^{\circ} \mathrm{C}$. There are several rivers which flow into the Osaka Bay. The largest river among them is the Yodo River with the average discharge rate of about $250 \mathrm{~m}^{3} / \mathrm{s}$. The study area, Tannowa, is located in the suburban area, and no large river exists near there.

The newly developed continuous heat-type

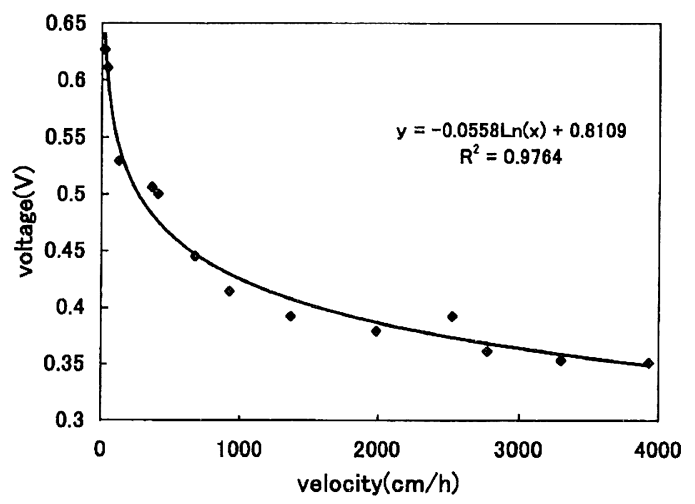

Figure 3 Relationship between water velocity $(\mathrm{cm} / \mathrm{h})$ and output voltage $(\mathrm{V})$ generated from temperature gradient between upstream and downstream water in the pipe.

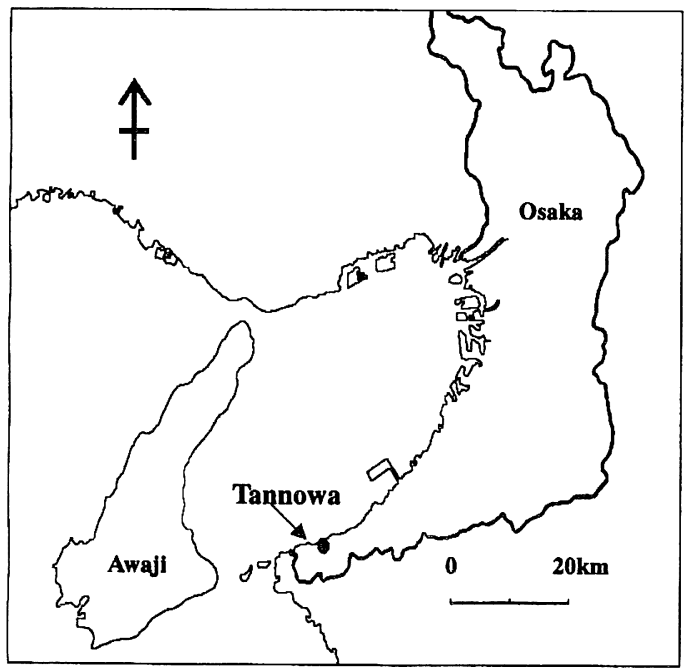

Figure 4 Location of the study area. 
automated seepage meter was set up at $5 \mathrm{~m}$ from the coastal line. The average depth of the sea water at the location of the seepage meter is $2.5 \mathrm{~m}$ from the surface. The area of the chamber with the diameter of $57 \mathrm{~cm}$ for the seepage meter is $0.255 \mathrm{~m}^{2}$. Measurements of SGD using the continuous heat type automated seepage meter have been done from June 7 to July 31,2000 , every ten minutes. The total number of the seepage data is 6870. The tidal (sea) levels were recorded at $5 \mathrm{~km}$ south of the study area every $60 \mathrm{~min}$.

\section{Tidal effects on SGD}

Figure 5 shows an example of the variations of hourly averaged SGD obtained by a continuous heat-type automated seepage meter in Tannowa, Osaka Bay, Japan. As can be seen from Figure 5, SGD rate changes with semi-diurnal periods. Figure 5 also shows that SGD rate decreases with increasing tidal (sea) level. This can be attributed to the decrease in hydraulic gradient between the groundwater and the seawater when the sea level increases at high tide. On the other hand, SGD increases with decreasing sea level. This tidal effect on SGD was also found by Lee (1977) using manual seepage me- ters. However, the resolution of the signal of the tidal effect of SGD is much clear in this study, because the newly developed automated seepage meter was used to evaluate SGD continuously and automatically. Therefore, it can provide longer-term and higher-resolution measurements of SGD which will help us to understand temporal scale issues on SGD and the relevant hydrological and coastal oceanographic processes.

Figure 6 also shows the changes in hourly averaged SGD rates and the tidal levels on June 15, 2000. As can be seen from Figure 6, some degree of time lag exists between the maximum of the SGD rate and the minimum of the tidal level. It seems that SGD becomes maximum about 4 to 5 hours behind tidal minimum. This delay may be caused by the resistance of groundwater discharge in the aquifer.

In order to evaluate this time lag between the maximum of the SGD rate and the minimum of the tidal level, deviations of the relationships between SGD rate and sea level were compared with the different time lag. Figure 7 shows the relationship between SGD velocity and the tidal level under the assumption that SGD delays 5 hours behind sea level. Although the relationship varies widely $(R=0.12)$, the de-

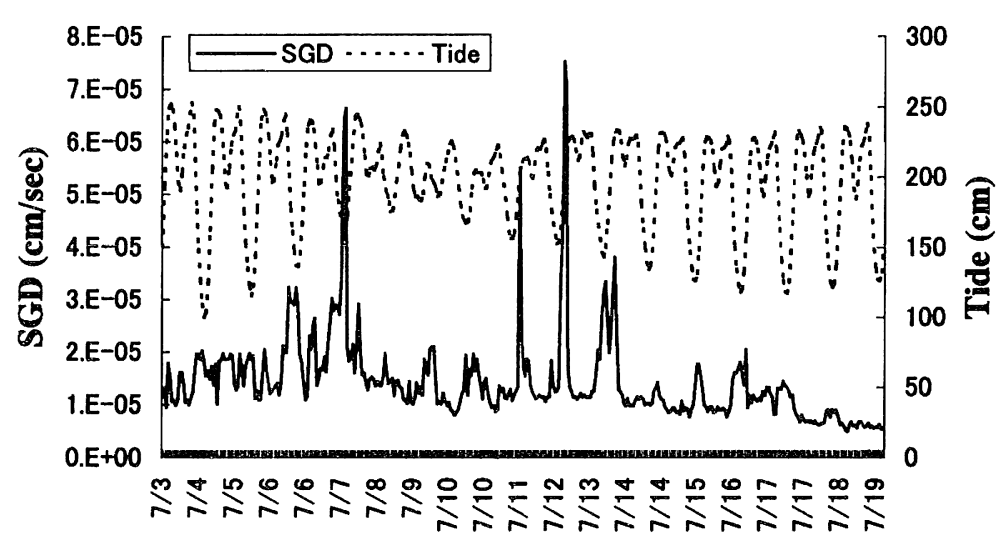

Figure 5 Variations of the SGD rates at Tannowa, south of Osaka Bay, Japan, and sea levels at the location of $5 \mathrm{~km}$ south of the study site. 


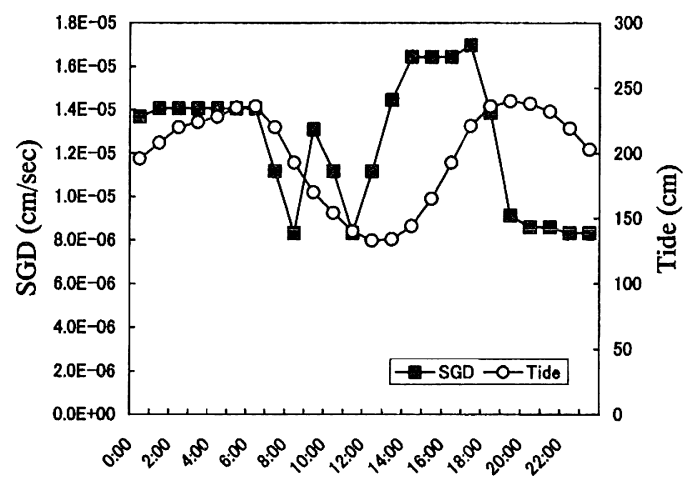

Figure 6 Variations of the SGD rates and sea levels on June 15,2000 at Tannowa, south of Osaka Bay, Japan.

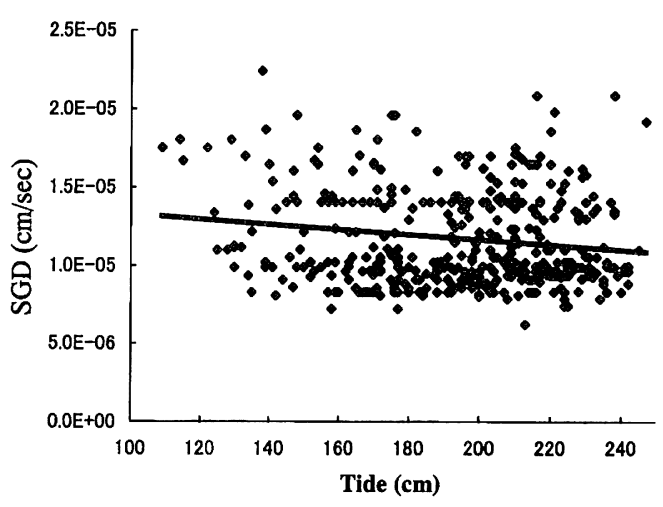

Figure 7 Relationships between SGD velocity and tidal levels under the assumption that SGD delays 5 hours behind sea level changes $(R=0.12)$.

viation is the minimum when the time lag between SGD and sea level is 5 hours (SGD is 5 hours behind sea level changes). There are still uncertainties why the SGD is delayed 5 hours behind sea level changes, however, the measurements using this automated seepage meter with other relevant hydrological measurements may reveal hydrological and coastal oceanographic processes near shore.

\section{Conclusions}

A "continuous heat-type" automated seep- age meter based on the effect of heat convection was newly developed to evaluate submarine groundwater discharge rates continuously and automatically. The basis of the method of this meter is measurement of the temperature gradient of the water between the downstream and upstream positions in a pipe. After calibrating sensors in the laboratory under the control of the known water flux, the automated seepage meter was applied to the measurements of SGD in Tannowa, Osaka Bay, Japan. Semi-diurnal periodical changes in SGD were found in Tannowa. This is attributed to the tidal effects on SGD. The time lag between the maximums of the SGD rate and the minimums of the tidal level was also found to be about 5 hours. The newly developed automated seepage meter can provide longer-term and higher-resolution measurements of SGD which will help to understand the relevant hydrological and coastal oceanographic processes.

\section{Acknowledgements}

We would like to thank the staff in Marine Youth Center, Osaka Prefecture, Japan, for their helps in the field. This study is financially supported in part by the Scientific Research Grant 11874064 from Ministry of Education, Sciences and Culture, Japan.

\section{References}

Belanger, T.V. and M.E. Montgomery, Seepage meter errors, Limnol. Oceanogr. 37, 1787-1795, 1992.

Boyle, D.R., Design of a seepage meter for measuring groundwater fluxes in the nonlittoral zones of lakesEvaluation in a boreal forest lake, Limnol. Oceanogr. 39, 670-681, 1994.

Burnett, W.C., Offshore springs and seeps are focus of working group. EOS, 80, 13-15, 1999.

Cable, J.E., W.C. Burnett and J.P. Chanton, Magnitude and variations of groundwater seepage along a Florida marine shoreline, Biogeochemistry, 38, 189-205, 1997a. 
Cable, J.E., W.C. Burnett J.P. Chanton, D.R. Corbett and P.H. Cable, Field evaluation of seepage meters in the coastal marine environment, Estuarine, Coastal and Shelf Science, 45, 367-375, 1997b.

Cherkauer, D.S. and J.M. McBride, A remotely operated seepage meter for use in large lakes and rivers, Ground Water, 26, 165-171, 1988.

Fellows, C.R. and P.L. Brezonik, Seepage flow into Florida lakes, Water Resour. Bull., 16, 635-641, 1980.

Fukuo, Y., Studies on groundwater seepage in the bottom of Lake Biwa, Report for Environmental Sciences by the Ministry of Education, Science and Culture, Japan, B289-R-12-2, 1-23, 1986.

Granier, A., Une nouvelle methode pour la measure du flux de seve brute dans tronc desarbres, Ann. Sci. For, 42, 81-88, 1985.

Israelsen, O.W. and R.C. Reeve, Canal lining experiments in the delta area, Utah, Utah Agr. Exp. Sta. Tech. Bull., No.313, 52pp, 1944.

Krupa, S.L., T.V. Belanger, H.H. Heck, J.T. Brok and B.J. Jones, Krupaseep-the next generation seepage meter, J. Coastal Res., 25, 210-213, 1998.

Lee, D.R., A device for measuring seepage flux in lakes and estuaries, Limnol. Oceanogr., 22, 140-147, 1977.

Libelo, E.L. and W.G. MacIntyre, Effects of surface-water movement on seepage-meter measurements of flow through the sediment-water interface, Hydrogeology Journal, 2, 49-54, 1994.

Paulsen, R.J., C.F. Smith and T. Wong, Development and evaluation of an ultrasonic groundwater seepage meter, Geology of Long Island and Metropolitan New York, Program with Abstracts, Long Island Geologists, State University of New York, Stony Brook, NY, 88-97, 1997.

Sayles, F.L. and W.H. Dickinson, The seep meter: a benthic chamber for the sampling and analysis of low velocity hydrothermal vents, Deep-Sea Research, 88, 1-13, 1990.

Shaw, R.D. and E.E. Prepas, Anomalous, short-term influx of water into seepage meters, Limnol. Oceanogr., 34, 1343-1351, 1989.

Shaw, R.D. and E.E. Prepas, Groundwater-lake interactions: I. Accuracy of seepage meter estimations of lake seepage, J. Hydrol., 119, 105-120, 1990a.

Shaw, R.D. and E.E. Prepas, Groundwater-lake interactions: II. Nearshore seepage patterns and the contribution of ground water to lakes in central Alberta, J. Hydrol., 119, 121-136, 1990b.

Taniguchi, M. and Y. Fukuo, Continuous measurements of ground-water seepage using an automatic seepage meter, Ground Water, 31, 675-679, 1993.

Taniguchi, M. and Y. Fukuo, An effect of seiche on groundwater seepage rate into Lake Biwa, Japan, Water Resour. Res., 32, 333-338, 1996.

Taniguchi, M., Interaction between groundwater and surface water/sea water; 4 Groundwater-sea water Interaction, Journal of Groundwater Hydrology, 43, 189-199, 2001.

Taniguchi, M., Burnett, W.C., Cable, J. E. and Turner, J., Investigation of submarine groundwater discharge, Hydrol. Process., (in press), 2001. 